\title{
Austenite and Forging Effects on 18Cr-18Mn Stainless Steel Impedance
}

\author{
R. Reyes-Hernández ${ }^{a, k}$, A. Torres-Islas ${ }^{b}$, S. Serna ${ }^{a}$, A. Molina-Ocampo ${ }^{a}$, J. Colin ${ }^{b}$ and A. Bedolla ${ }^{c}$ \\ ${ }^{1}$ UAEM, Institute of Basic Engineering and Applied Sciences (IICBA), Av. Universidad 1001, Col. Chamilpa, 62209 Cuernavaca, \\ Morelos, Mexico. \\ ${ }^{2}$ School of Chemical Science and Engineering, PE. Ing. Mechanical, Universidad Autónoma del Estado de Morelos (UAEM), \\ Av. Universidad 1001, Col. Chamilpa, 62209 Cuernavaca, Morelos, Mexico. \\ ${ }^{3}$ Metallurgical Research Institute, Universidad Michoacana de San Nicolás de Hidalgo. Gral. Francisco J. Mujica S / N Felicitas River 58030, \\ Morelia, Michoacán, Mexico.
}

Received 14 December 2016, revised 5 July 2017, accepted 17 July 2017.

\begin{abstract}
The influence of the austenite phase (gamma iron dissolved in carbon) in the corrosion resistance of $18 \mathrm{Cr}-18 \mathrm{Mn}$ steel was studied. The percentage of austenite in the steel was calculated using the $\left(\mathrm{Cr}_{\mathrm{eq}} / \mathrm{Ni}_{\mathrm{eq}}\right)$ equation. In order to obtain the impedance value of the steel exposed to a corrosive saline environment, Bode diagrams were obtained at 8,16 and 24 hours of exposure. The results obtained indicate that an increase of the austenite phase in the steel, also produces an increase in various steel properties, such as steel impedance and polarization resistance $(\mathrm{Rp})$. On the other hand, it was observed that the impedance value of the forged $18 \mathrm{Cr}-18 \mathrm{Mn}$ steel increases when the steel is immersed in a saline solution.
\end{abstract}

KEYWORDS

Polarization resistance, austenite, Bode diagram, stainless steel, forging.

\section{Introduction}

Among the various phases that present in steel, there exist the austenite phase, which is gamma iron dissolved in carbon. Gamma iron forms in the $910^{\circ} \mathrm{C}$ to $1400^{\circ} \mathrm{C}$ range, crystallizes in a face-centred cubic crystal structure (FCC); cube gamma iron has more volume than alpha iron, dissolves more easily in carbon, and renders a nonmagnetic steel that has high ductility. ${ }^{1,2}$

These $18 \mathrm{Cr}-18 \mathrm{mn}$ steels are used for the retainer rings in gas turbine electric generators. This steel arose from a need for steel that is not susceptible to stress corrosion cracking (SCC). ${ }^{3,4}$ The failures in this steel are generally related to crack propagation. ${ }^{5}$ It is therefore important to determine the corrosion resistance of materials used in retainer ring manufacturing, because the rings are subject to stresses which may cause failures in generators due to rotational speed, corrosion environment and basic corrosion. Because the working environment (generalized or localized) affects steel, it is necessary to undertake basic studies to determine steel corrosion resistance and corrosion type. These steels may suffer general or localized corrosion, the main variables being the type of corrosion, corrosion rate, corrosion resistance, incremental corrosion resistance, whether or not there is the formation of a protective layer on the steel, the effect of an austenite phase, and steel constituents that may cause different behaviours. The use of different electrochemical techniques will allow better prediction of the processes involved in steel corrosion. Rawers studied six steels, namely a duplex phase (ferrite + austenite) steel, three austenite phase steels (FCC) and two austenite phase (FCC) + M23C6 carbide steels, ${ }^{6}$ and could predict the phases presents in $18 \mathrm{Cr}-18 \mathrm{mn}$ steel using a Shauffler diagram. ${ }^{7}$

The addition of nitrogen to steel promotes its properties. ${ }^{8}$ Interstitial nitrides in steel can lead to increased cracking. ${ }^{9}$ These chromium nitrides have high stability. ${ }^{10}$

* To whom correspondence should be addressed. E-mail: r..c204@ hotmail.com
In this article we provide new information on $18 \mathrm{Cr}-18 \mathrm{mn}$ steel, including Bode diagrams, which indicate steel polarization resistance; this basic corrosion test has to date not been applied to $18 \mathrm{Cr}-18 \mathrm{Mn}$ steel.

Our work is based on an electrochemical impedance technique (EIT), which allowed us observe the increase in $Z^{\prime \prime}$ impedance (indicative of steel corrosion resistance). EIT is an electrochemical method used in corrosion studies; it is effective and provides information on what happens to the steel during degradation (charge transfer, diffusion of species, to mention some of the mechanisms). We also provide an indication of the steel corrosion resistance.

\section{Experimental Procedure}

We developed four steels: 1) $18 \mathrm{Cr}-18 \mathrm{mn}$ steel, 2) nitriding steel $18 \mathrm{Cr}-18 \mathrm{Mn}$; 3) $18 \mathrm{Cr}-18 \mathrm{Mn}$ forged steel, and 4) $18 \mathrm{Cr}-18 \mathrm{Mn}$ forged and nitrided steel. We produced the $18 \mathrm{Cr}-18 \mathrm{mn}$ steel in a magnetic induction furnace at the 'Instituto de Investigación en Metalurgia y Materiales' of the 'Universidad Michoacana de San Nicolás de Hidalgo', Michoacán, Mexico.

The $18 \mathrm{Cr}-18 \mathrm{Mn}$ steel developed by us had a new composition of analytical grade elements. The elements were melted at $1650{ }^{\circ} \mathrm{C}$ and the material was homogenized by the rotating action of the induction furnace throughout the process. The composition of the steel was $61.24 \%$ iron, $18 \%$ chromium, $17 \%$ manganese, $1.8 \%$ silicon and $1.96 \%$ carbon.

In our electrochemical corrosion test, Bode diagrams were obtained at 8,16 and $24 \mathrm{~h}$ with the steel in saline solution $(3.5 \%$ $\mathrm{NaCl}$ in distilled water). We used an amplitude of $10 \mathrm{mV}$ with a frequency range of $1 \mathrm{mHz}$ to $10 \mathrm{KHz}$. We repeated the experiment six times.

For nitriding steel, we nitrided the $18 \mathrm{Cr}-18 \mathrm{Mn}$ steel via plasma, using a mixture of nitrogen and hydrogen gasses (20:80, respec- 
tively) over a period of $8 \mathrm{~h}$ with $300 \mathrm{~V}$ of potential and $0.12 \mathrm{~A}$ of current. We maintained a constant pressure (3 Torr) inside the chamber.

For forging, we raised the steel temperature to $1100{ }^{\circ} \mathrm{C}$ in a muffle and forged it at constant pressure.

The presence of the austenite stability phase in the steel was determined by applying the equation $\left(\mathrm{Cr}_{\text {eq }}\left(\mathrm{Ni}_{\text {eq }}\right)\right.$, and this was confirmed by X-ray diffraction.

The nitrogen concentration in the nitrided steel was determined by scanning electron microscopy (SEM).

From our electrochemical test (Bode diagrams), we could determine the level of steel polarization resistance at 8,16 and $24 \mathrm{~h}$ while keeping the steel in a corrosive medium.

Finally we calculated the steel corrosion rates.

\section{Results and Discussion}

\subsection{Austenite Phase Presence in Steel}

For $18 \mathrm{Cr}-18 \mathrm{mn}$ steel, the chromium and nickel equivalents were determined using Equations 1 and 2. ${ }^{7}$

$$
\begin{aligned}
& \text { Cr equivalent }=\mathrm{Cr}+\mathrm{Mo}+(1.5)(\mathrm{Si}) \\
& \text { Ni equivalent }=\mathrm{Ni}+(.87)(\mathrm{Mn})+(30)(\mathrm{C})+(18)(\mathrm{N})
\end{aligned}
$$

For $18 \mathrm{Cr}-18 \mathrm{mn}$ steel, $\mathrm{Cr}$ equivalent $=20.7$ and $\mathrm{Ni}$ equivalent $=$ 73.59 .

Thus:

$$
\left(\mathrm{Cr}_{\text {eq }} / \mathrm{Ni}_{\text {eq }}\right)=20.7 / 73.59=0.2812 \text {, }
$$

which indicated that our $18 \mathrm{Cr}-18 \mathrm{Mn}$ steel was in the stainless steel range. The low value $\left(\mathrm{Cr}_{\mathrm{eq}} / \mathrm{Ni}_{\mathrm{eq}}\right)$ indicated that in this solidification type of steel the austenite phase is unchanged, and that the steel is in a stable state.

For $18 \mathrm{Cr}-18 \mathrm{mn}$ nitrided steel, $\mathrm{Cr}_{\mathrm{eq}}=20.7$ and $\mathrm{Ni}_{\mathrm{eq}}=83.67$. Thus:

$$
\left(\mathrm{Cr}_{\text {eq }} / \mathrm{Ni}_{\text {eq }}\right) \text { nitrided steel }=20.7 / 83.67=0.2474 \text {, }
$$

which indicated than the austenite phase of steel that was nitrided is even more stable than $18 \mathrm{Cr}-18 \mathrm{Mn}$ steel, because by reducing the resulting numerical value $\left(\mathrm{Cr}_{\mathrm{eq}} / \mathrm{Ni}_{\mathrm{eq}}\right)$, the stability of the austenite phase is increased. Several researchers have found a similar relationship between this behaviour and the addition of nitrogen.

The XRD study was performed with reference to international tables of crystallography (Figs. 1-4).

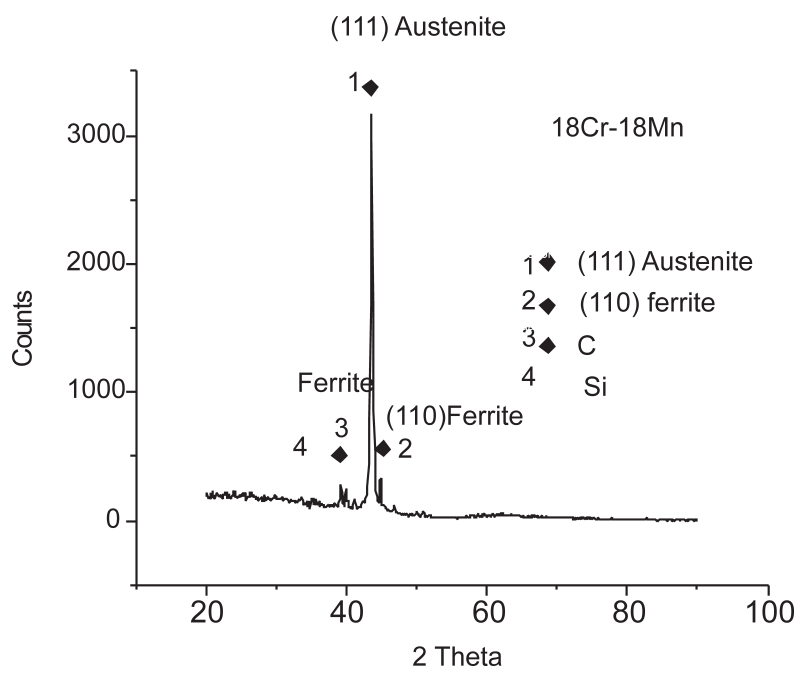

Figure 1 18Cr-18Mn XRD showing the austenite phase in (111).

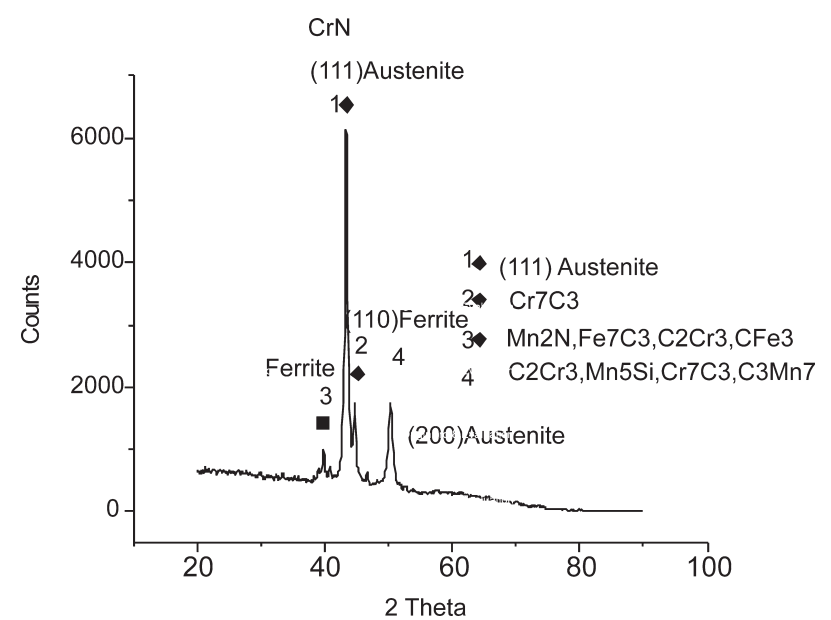

Figure 2 18Cr-18Mn-N XRD showing the phase in (111) and (200) and CrN.

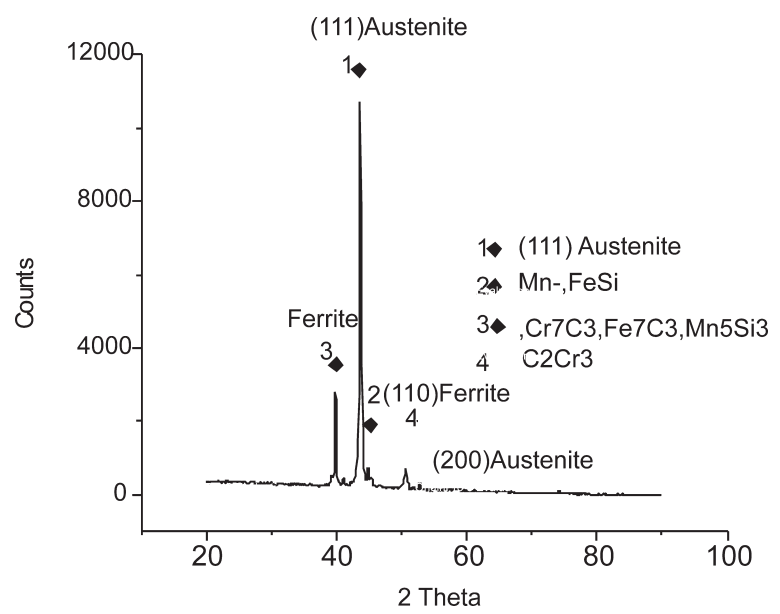

Figure 3 18Cr-18Mn-F XRD showing the austenite phase in (111) and (200).

\subsection{Corrosion Rate and Bode Diagrams}

Corrosion rate to linear polarization (LPR) tests showed that the $18 \mathrm{Cr}-18 \mathrm{Mn}$ steel's corrosion rate was $2397.3 \mu \mathrm{m} \mathrm{yr}^{-1}$ compared to, $555.5 \mu \mathrm{m} \mathrm{yr}^{-1}$ for nitrided steel, $859.09 \mu \mathrm{m} \mathrm{yr}^{-1}$ for forged steel, and $1.818 \times 10^{-3} \mu \mathrm{m} \mathrm{yr}^{-1}$ for forged and subsequently nitrided steel. These results are consistent with those of potentiodynamic polarization. ${ }^{11}$

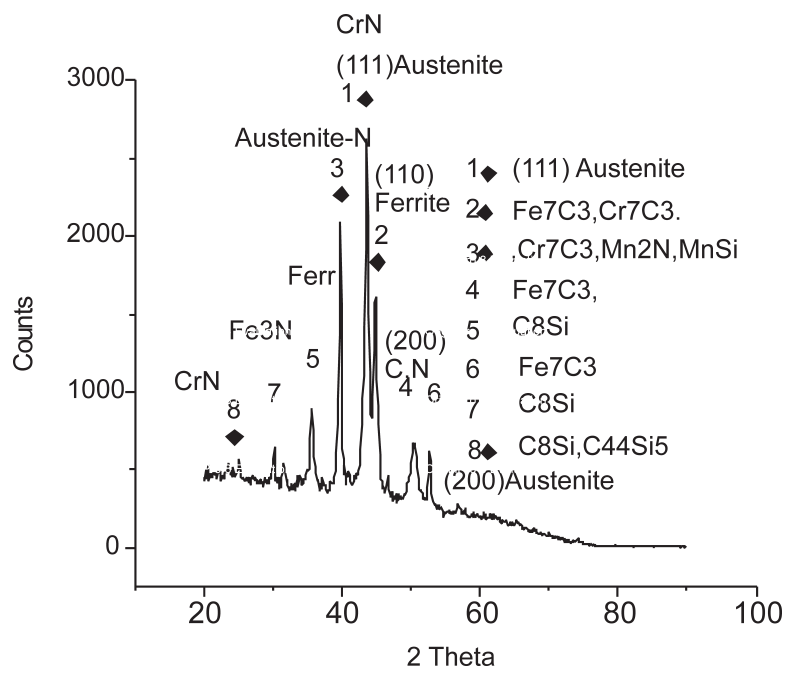

Figure 4 18Cr-18Mn-F-N XRD showing the austenite phase in and CrN formations. 
From Table 1 we can conclude that the forged and nitrided $18 \mathrm{Cr}-18 \mathrm{mn}$ steel is the only one that presents a negligible corrosion rate.

Nitrogen increments the austenite phase in the steel. Hartline found than austenitic steels are more resistant to pitting corrosion than duplex steels, and more resistant than ferritic steels, which is an additional factor in the properties of austenitic steels. ${ }^{12}$ Zhang et al. found cell $\mathrm{Cr}_{2} \mathrm{~N}$ and Chi phase, in which they attributed the increase in resistance to the bite of austenitic nitrided steel. ${ }^{13}$

Figures 5, 6, 7 and 8 show the impedance values our steels, which is related to corrosion resistance, at $8 \mathrm{~h}$. The value for forged-nitrided $18 \mathrm{Cr}-18 \mathrm{mn}$ is the largest; this steel has an extremely high corrosion resistance value compared to the other three steels. Mandi found expanded austenite (protective white layer) and to this he attributed the high corrosion resistance of nitrided steel. ${ }^{14}$ Toshkov et al. also mentioned corrosion resistance properties because expanded austenite formed due to nitrides. ${ }^{15}$ This agrees with our corrosion rate as the rate of corrosion of this steel was the one with the lowest value. Their steel that had the lowest impedance value is the $18 \mathrm{Cr}-18 \mathrm{Mn}$ steel, close to $90 \mathrm{ohms} \mathrm{cm}^{-2}$. This is consistent with our results on corrosion rate; besides, we found that this steel has a higher rate of corrosion. We repeated the experiment six times..

Figures 9-12 and 13-16 show the corrosion behaviour of the studied steels through their Bode diagrams obtained at $16 \mathrm{~h}$ and

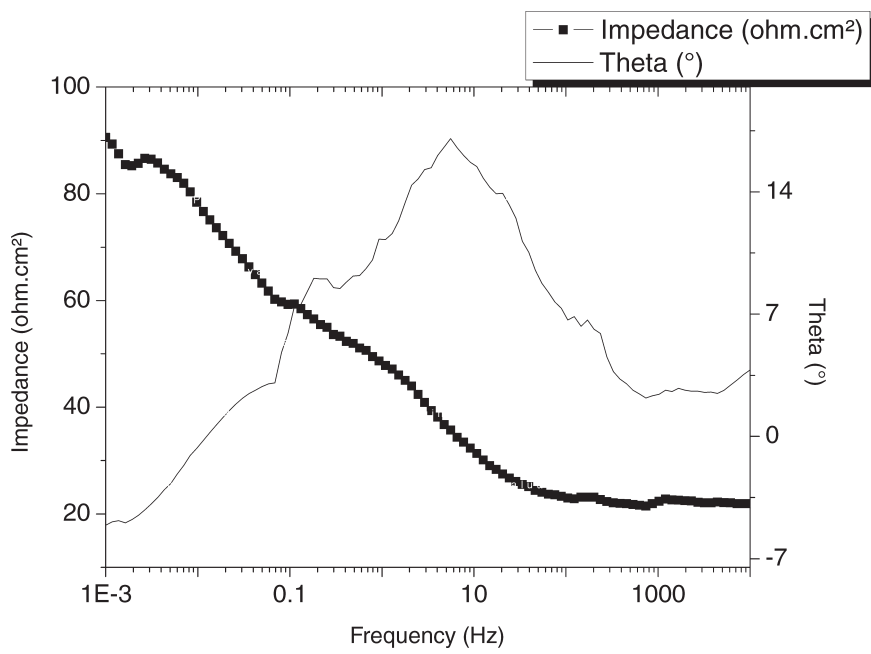

Figure 5 18Cr-18Mn Bode diagram, $8 \mathrm{~h}$.

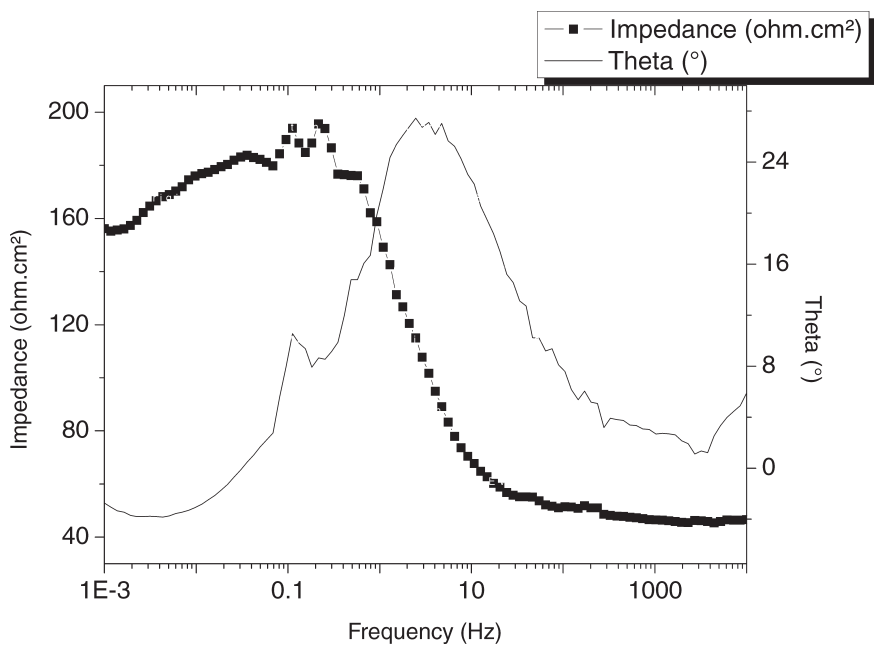

Figure 7 Nitrided 18Cr-18Mn Bode diagram, $8 \mathrm{~h}$.
Table 1 Stainless steel corrosion level from corrosion rate.

\begin{tabular}{cl}
\hline Corrosion rate $\left(\mu \mathrm{m} \mathrm{yr}^{-1}\right)$ & Corrosion level \\
\hline$<1$ & Insignificant \\
$1-5$ & Low \\
$5-10$ & Moderate \\
$>10$ & High \\
\hline
\end{tabular}

$24 \mathrm{~h}$, respectively, of staying immersed in a saline medium. The impedance higher value was for the forged and nitrided steel. The lower impedance value was for $18 \mathrm{Cr}-18 \mathrm{Mn}$ steel, his impedance varies of steel that was immersed for a longer time can be ascrided to corrosion products being added to the saline solution, resulting in a change in the aggressiveness of the medium.

It is of importance to note that over time, for steels that were not forged, the impedance values usually increased, while for forged steels the impedance decreased. This may be because the corrosion products of forged steel render the medium less corrosive, while for the steel that was not forged, the corrosion products become more aggressive. This pattern leads us to conclude that since forged steel increases in corrosion resistance over time while remaining in the same saline solution, the forged corrosion products could be used as anti-corrosion materials in corrosive solutions.

We repeated the experiment six times, and the resultant

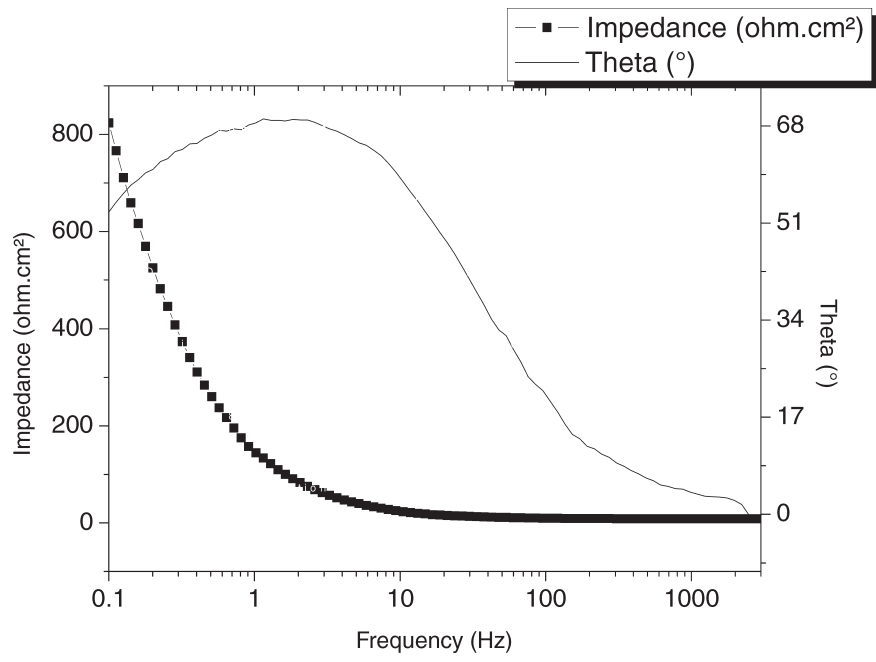

Figure 6 Forged 18Cr-18Mn Bode diagram, $8 \mathrm{~h}$.

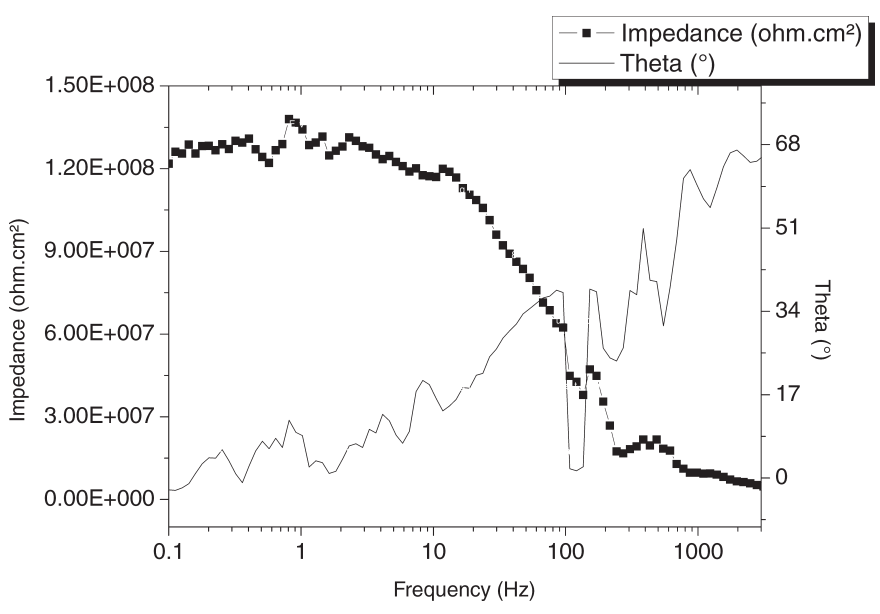

Figure 8 F-N 18Cr-18Mn Bode diagram, 8 h. 


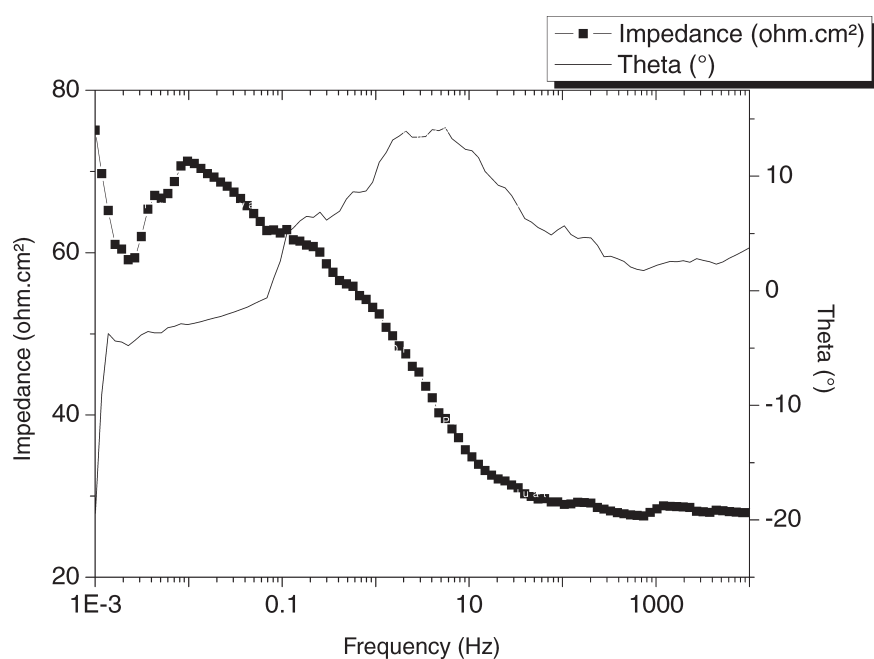

Figure 9 18Cr-18Mn Bode diagram, $16 \mathrm{~h}$.

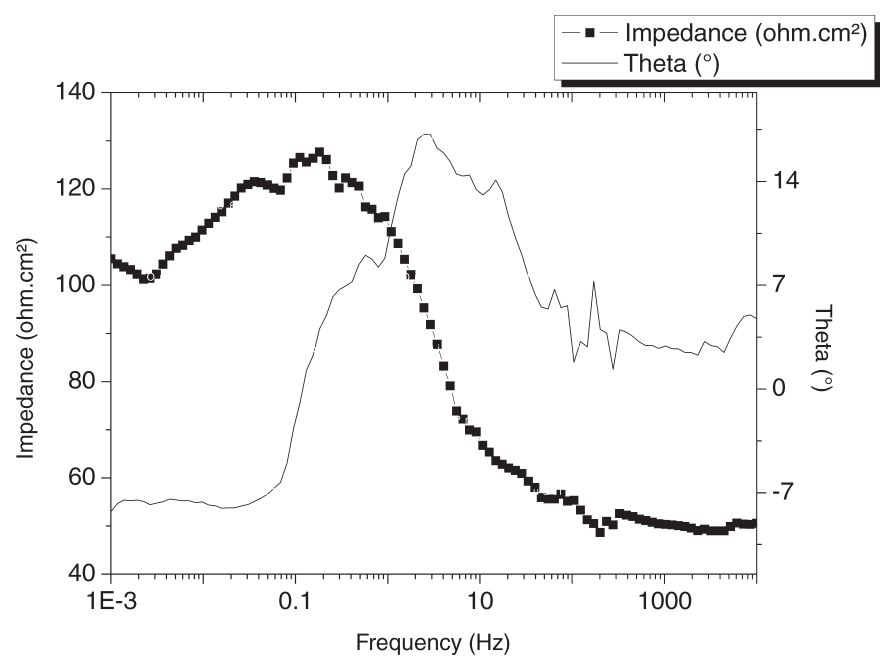

Figure 11 Nitrided 18Cr-18Mn Bode diagram, $16 \mathrm{~h}$.

impedance values are given in Table 2. Steel that was forged and later nitrided has the highest corrosion resistance, while the steel without forging and without nitriding is the least corrosion resistant. More importantly though, impedance values of steels that were forged increased in the course of the degradation time, which means that the corrosion products of forged steels act as corrosion inhibitors.

\section{Conclusions}

We have shown that steel that was nitrided has a lower $\left(\mathrm{Cr}_{\mathrm{ed}} / \mathrm{Ni}_{\mathrm{eq}}\right)$ value, indicating that is an austenitic stable steel, phase unchanged. The forged and nitrided $18 \mathrm{Cr}-18 \mathrm{mn}$ steel had the lowest corrosion value, an insignificant level of corrosion, better corrosion resistance, and also the highest impedance value according to the Bode diagrams. The great increase in impedance therefore suggest that steel should be nitrided and forged if a high impedance in saline environments is required. We also noted that the impedance of forged steel increased over time in in a saline environment, indicating that the corrosion products render the medium less aggressive over time.

Higher corrosion resistance was observed for steel that was forged and nitrided, and this is attributed to surface nitrides,

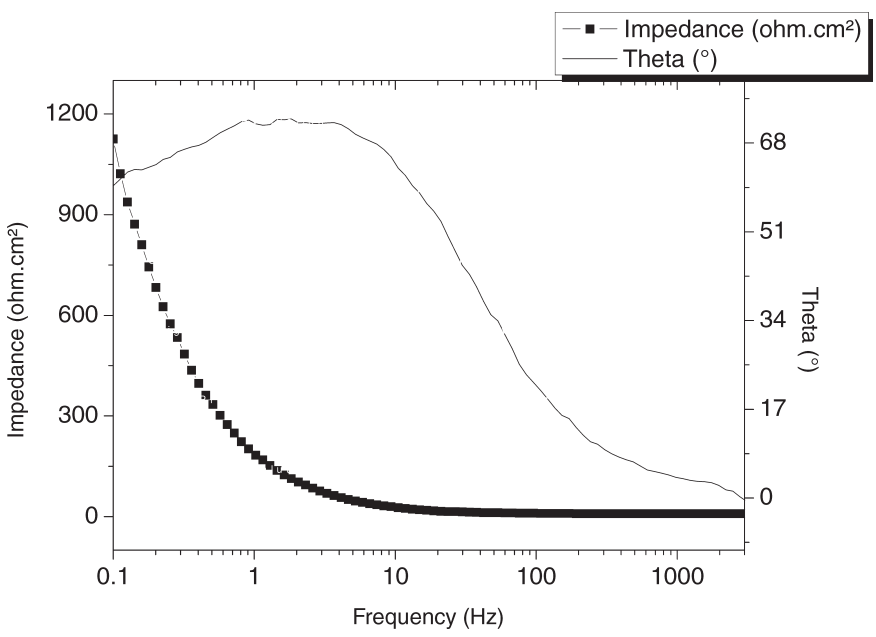

Figure 10 Forged 18Cr-18Mn Bode diagram, $16 \mathrm{~h}$.

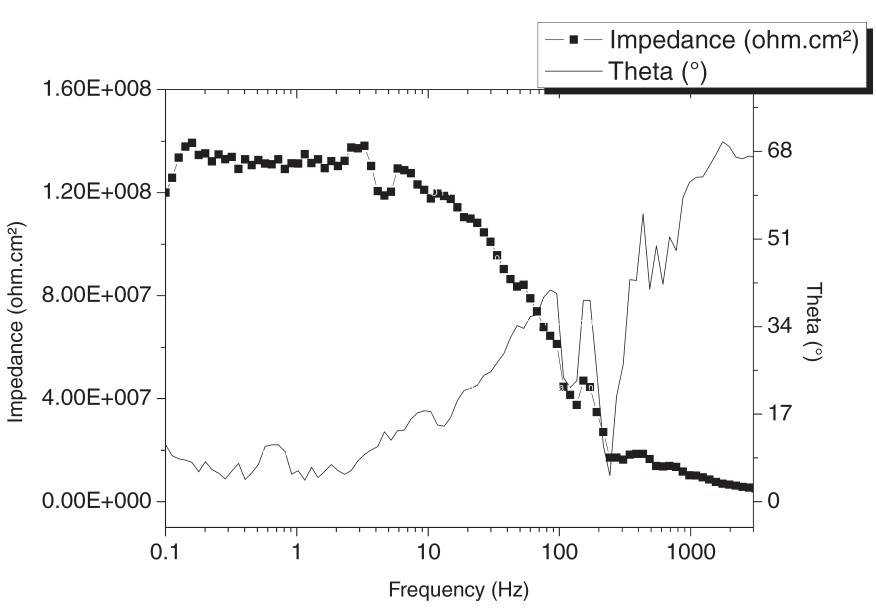

Figure $12 \mathrm{~F}-\mathrm{N}$ 18Cr-18Mn Bode diagram, $16 \mathrm{~h}$.

Table 2 Impedance values $\left(\mathrm{Ohm} \mathrm{cm}^{-2}\right)$ obtained from Bode diagrams at 8,16 and $24 \mathrm{~h}$. We repeated the experiment six times.

\begin{tabular}{|c|c|c|c|}
\hline Steel/time & Impedance & Standard deviation & $\%$ Error \\
\hline \multicolumn{4}{|c|}{$8 \mathrm{~h}$} \\
\hline 18Cr-18Mn & 90 & 0.36878 & 0.3555 \\
\hline 18Cr-18Mn-F & 800 & 1.2649 & 0.1 \\
\hline 18Cr-18Mn-N & 155 & 0.7720 & 0.4387 \\
\hline 18Cr-18Mn-F-N & $1.28 \times 10^{8}$ & 0 & 0 \\
\hline \multicolumn{4}{|c|}{$16 \mathrm{~h}$} \\
\hline 18Cr-18Mn & 73 & 0.228 & 0.2739 \\
\hline 18Cr-18Mn-F & 1100 & 1.2649 & 0.07272 \\
\hline $18 \mathrm{Cr}-18 \mathrm{Mn}-\mathrm{N}$ & 105 & 0.116 & 0.2666 \\
\hline $8 \mathrm{Cr}-18 \mathrm{Mn}-\mathrm{F}-\mathrm{N}$ & $1.29 \times 10^{8}$ & 0 & 0 \\
\hline \multicolumn{4}{|c|}{$24 \mathrm{~h}$} \\
\hline $18 \mathrm{Cr}-18 \mathrm{Mn}$ & 56 & 0.08944 & 0.1428 \\
\hline 18Cr-18Mn-F & 930 & 0.8944 & 0.08602 \\
\hline $18 \mathrm{Cr}-18 \mathrm{Mn}-\mathrm{N}$ & 98 & 0.2828 & 0.2448 \\
\hline 18Cr-18Mn-F-N & $1.5 \times 10^{8}$ & 0 & 0 \\
\hline
\end{tabular}




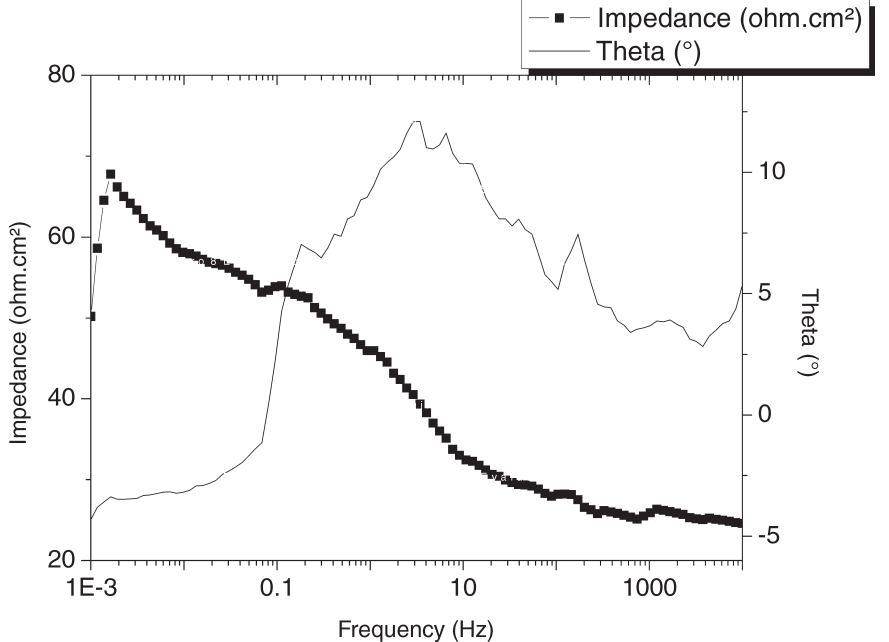

Figure 13 18Cr-18Mn Bode diagram, $24 \mathrm{~h}$.

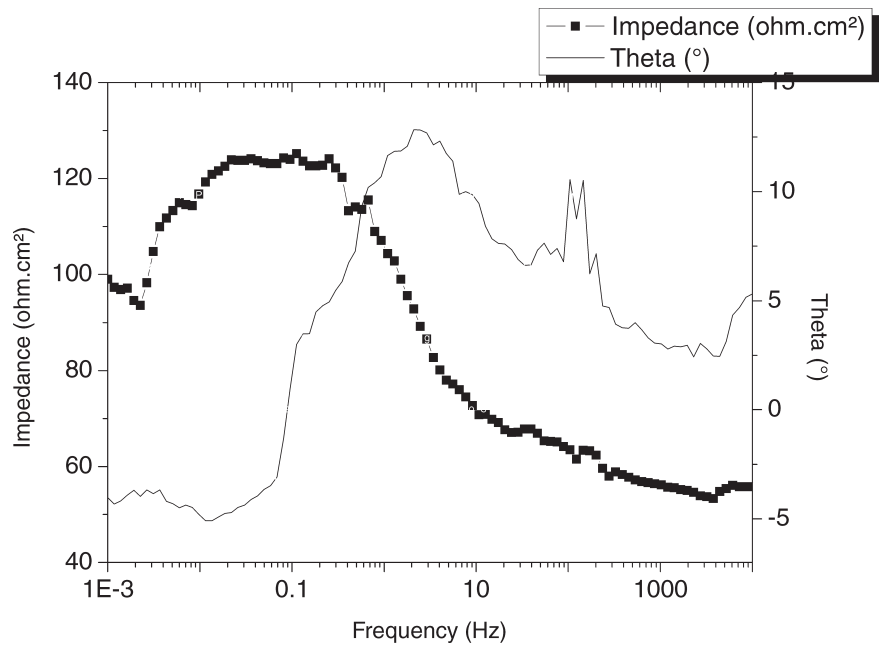

Figure 15 Nitrided 18Cr-18Mn Bode diagram, $24 \mathrm{~h}$.

chemical composition of the material, chemical stability, the ability to prevent the diffusion of metallic ions and their structural high order.

One of the most important observations with respect to forged steel is that over a period time its impedance increased due to corrosion products. With respect to the addition of nitrogen via plasma, it was observed that this greatly increased the corrosion resistance of steel due to the formation of a passive layer by the nitrides of chromium and a white layer called austenite expanded or phase 'S'

\section{References}

1 L. Bracke, J. Penning and N. Akdut, The influence of Cr and N additions on the mechanical properties of FeMnC steels, Metall. Mater. Trans. A, 2007, 38(3), 520-528.

2 C.W. Shao, F. Shi and X.W. Li, Influence of cyclic stress amplitude on mechanisms of deformation of a high nitrogen austenitic stainless steel, Mater. Sci. Eng. A, 2016, 667, 208-216.

3 O.I. Balyts'kyi, Corrosion-mechanical characteristics of the mterials of non magnetic retaining rings of turbogenerators. II high-nitrogen 18Mn-18Cr steels, Mater. Sci., 1998, 34(2), 115-122.

4 J. Ishizaka, Development and production of $18 \mathrm{Cr}-18 \mathrm{Mn}$ non-magnetic retaining ring with high yield strength, ISIJ Int., 1990, 30(8), 587-593.

5 S. Liu, D. Liu and S. Liu, Transgranular fracture in low temperature

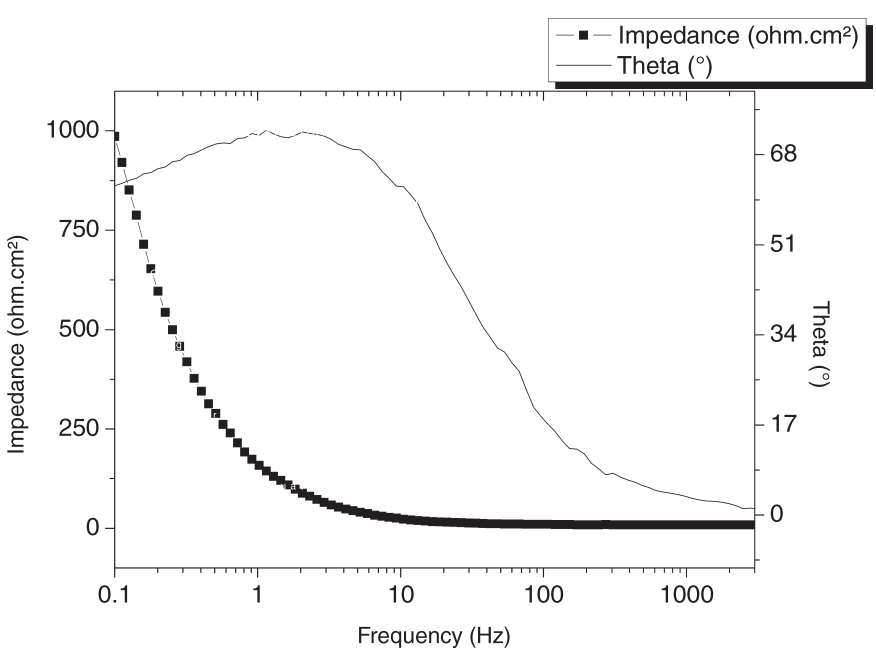

Figure 14 Forged 18Cr-18Mn Bode diagram, $24 \mathrm{~h}$.

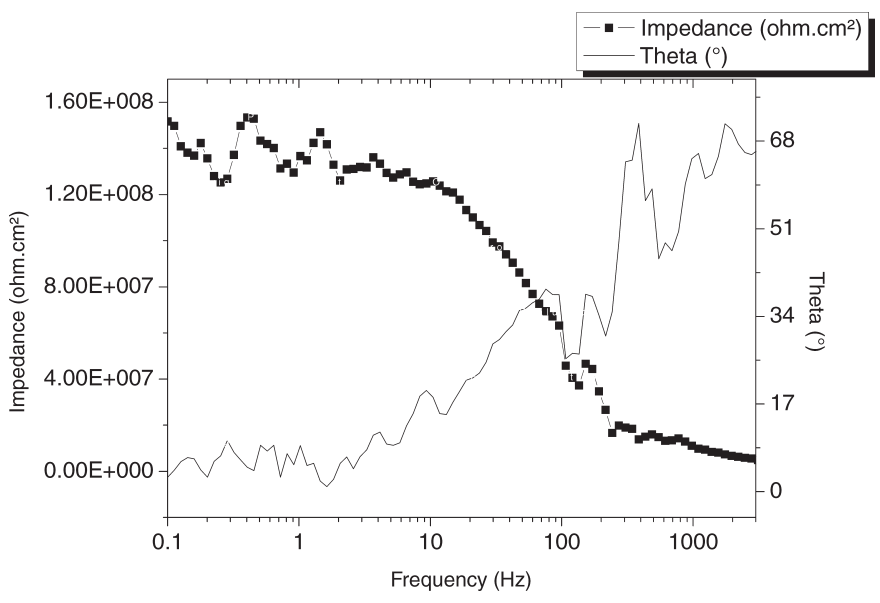

Figure 16 F-N 18Cr-18Mn Bode diagram, $24 \mathrm{~h}$.

brittle fracture of high nitrogen austenitic steel, J. Mater. Sci., 2007, 42(17), 7514-7519.

6 J. Rawers, Oxidation characteristics of $\mathrm{Fe}-18 \mathrm{Cr}-18 \mathrm{Mn}$-stainless steel alloys, Oxid. Met., 2010, 74(3-4), 167-178.

7 J.C. Rawers, Alloying effects on the microstructure and phase stability of Fe-Cr-Mn steels, J. Mater. Sci., 2008, 43(10), 3618-3624.

8 J. Moon, T.H. Lee, J.H. Shin and J.W. Lee, Hot working behavior of a nitrogen-alloyed $\mathrm{Fe}-18 \mathrm{Mn}-18 \mathrm{Cr}-\mathrm{N}$ austenitic stainless steel, Mater. Sci. Eng. A, 2014, 594, 302-308.

9 H. Berns and K. Geenen, Hot strength and creep resistance of a high interstitial austenitic CrMn steel, Steel Res. Int., 2013, 84(8), 713-723.

10 S. Parascandola, W. Möller and D. L. Williamson, The nitrogen transport in austenitic stainless steel at moderate temperatures, 2000, Appl. Phys. Lett., 76(16), 2194.

11 R.R. Hernandez, A. Torres, S. Serna, A. Bedolla, A. Molina, J. Colin and $\mathrm{H}$. Martinez, Corrosion behavior of $18 \mathrm{Cr}-18 \mathrm{Mn}$ hot forged and plasma nitrided steel, J. Adv. Electrochem., 2016, 2(4), 117-120.

12 A.G. Hartline, The effect of nitrogen additions upon the pitting resistance of 18 Pct Cr, 18 Pct Mn stainless steel, Metall. Trans. 1974, 5, 5-10.

13 H.B. Li, Z.H. Jiang, Z. Li and Z.R. Zhang, Pitting susceptibility and semiconducting properties of passive films of $18 \mathrm{Cr}-18 \mathrm{Mn}-2 \mathrm{Mo}-0.9 \mathrm{~N}$ high nitrogen austenitic stainless steel, Adv. Mater. Res., 2009, 79-82, 993-996.

14 S. Maändl and B. Rauschenbach, Anisotropic strain in nitrided austenitic stainless steel, J. Appl. Phys., 2000, 88(6), 3323.

15 V. Toshkov, R. Russev, T. Madjarov, and E. Russeva, On low temperature ion nitriding of austenitic stainless steel AISI 316, JAMME, 2007, $25(1), 71-74$. 